\title{
PERTANIAN
}

\section{INDEKS KEKERINGAN (STANDARDIZED PRECIPITATION INDEX) SPI DAN PENGARUHNYA TERHADAP PRODUKTIVITAS HORTIKULTURA TAHUNAN DI KABUPATEN JEMBER}

\author{
Drought Index (Standard Presipitation Index) SPI And Its Effect On \\ Annual Productivity In Jember District
}

\section{Arzaky Ardi Surya Nugroho*, Cahyoadi Bowo, Joko Sudibya}

\author{
Program Studi Agroteknologi, Fakultas Pertanian Universitas Jember \\ Jl. Kalimantan 37, Kampus Tegal Boto, Jember 68121 \\ *E-mail : a.ardi.s.nugroho@gmail.com
}

\begin{abstract}
Perennial tropical horticulture is a superior product whose productivity is affected by water availability. The impact of climate fluctuations due to global warming affects the availability of ground water. This study aims to determine the effect of the Standardized Precipitation Index (SPI) drought index derived from rainfall data on the productivity of perennial horticulture (durian, avocado and rambutan). The study was conducted from July 2016 - November 2018 in 9 sub-districts in Jember Regency where has the highest production. Rainfall data is proceed into SPI data according to the guidelines of the WMO (World Meteorological Organization). Productivity data derived from production data divided by the number of plants. The results of 12 monthly SPI calculations compared with the perennial horticultural productivity data. To find out the relationship between productivity and SPI, the correlation method is used. The results showed that the appropriate SPI value for observing annual horticultural productivity was SPI 9 and 12 monthly. The value of SPI greatly influences the correlation of productivity of durian, avocado and rambutan.
\end{abstract}

Keywords: SPI, productivity, annual horticulture.

\section{ABSTRAK}

Tanaman hortikultura tropis tahunan adalah produk unggulan yang produktivitasnya dipengaruhi oleh ketersediaan air. Dampak fluktuasi iklim akibat pemanasan global mempengaruhi ketersediaan air tanah. Penelitian ini bertujuan untuk mengetahui pengaruh index kekeringan SPI yang berasal dari data curah hujan terhadap produktivitas hotikultura tahunan (durian, alpukat dan rambutan). Penelitian dilakukan mulai bulan Juli 2016 - November 2018 pada 9 Kecamatan dengan produksi tertinggi di Kabupaten Jember. Data curah hujan diolah menjadi data SPI sesuai pedoman WMO (World Meteorological Organization) dan data produktivitas berasal dari data produksi dibagi jumlah tanaman kemudian hasil perhitungan SPI 12 bulanan dibandingkan dengan data produktifitas hortikultura tahunan. Untuk mengetahui hubungan produktivitas dan SPI digunkan metode korelasi. Hasil penelitian menunjukkan nilai SPI yang sesuai untuk mengamati produktivitas hortikultura tahunan adalah SPI 9 dan 12 bulanan. Nilai SPI sangat berpengaruh terhadap korelasi produktivitas durian, alpukat dan rambutan. Nilai SPI yang semakin tinggi menaikkan produktivitas durian, tetapi menurunkan produktivitas alpukat dan rambutan.

Kata Kunci : SPI, produktifitas, hortikuktura tahunan

How to citate : Nugroho, A.A.S., Cahyoadi B., Joko S. 2019. Indeks Kekeringan (Standardized Precipitation Index) SPI dan Pengaruhnya Terhadap Produktivitas Hortikultura Tahunan di Kabupaten Jember. Berkala Ilmiah Pertanian, 2(4): 149-154.

\section{PENDAHULUAN}

Tanaman tropis terutama komoditas hortikultura tahunan merupakan aset bagi negara yang terletak di sepanjang garis katulistiwa, hal ini disebabkan tanaman tersebut hanya bisa tumbuh dengan suhu dan kelembapan yang sesuai dengan area tropis. Tanaman buah hortikultura termasuk dalam tanaman tropis yang menjadi komuditas andalan Indonesia yang merupakan negara tropis dengan wilayah luas dan memiliki banyak ekosistem endemik berbeda. Tanaman hortikultura tropis memiliki syarat tumbuh khusus yang terpaut dengan kondisi iklim yang mempengaruhi pertumbuhan dan perkembangannya. Tanaman hortikultura yang merupakan komoditi unggulan diantaranya durian, alpukat dan rambutan.

Dampak dari pemanasan global yang dirasakan di semua wilayah yaitu terjadinya perubahan iklim yang dirasakan antara lain adalaah pergantian musim yang tidak teratur dan bencana ekologis seperti banjir atau kekeringan yang datang silih berganti menimbulkan dampak kerugian yang nyata. Musim kemarau yang semakin panjang dan musim hujan yang lebih pendek menyebabkan berkurangnya beberapa sumber air yang berasal dari mata air di kawasan hutan. Dari segi sumberdaya lahan, adanya kekeringan yang berlebihan menyebabkan tanaman pertanian menjadi kering sehingga berdampak pada ancaman ketahanan pangan bagi masyarakat (Nandini dan Budi, 2011). Di daerah tropis dengan suhu yang hangat dan matahari bersinar sepanjang tahun, ketersediaan air sering menjadi pembatas pertumbuhan tanaman. Berbeda dengan unsur lahan lainnya yang relatif stabil, iklim terus berubah secara dinamis sehingga perlu diperkirakan untuk mengetahui kemungkinan ketersediaan air ke depan.

Kabupaten Jember yang memiliki topografi wilayah mulai gunung, pengunungan, perbukitan, dataran hinggga pesisir membentang dari arah utara ke selatan dan juga jenis tanah yang 
berbeda menyimpan potensi kemungkinan variabilitas iklim mikro beranekaragam bagi pertumbuhan tanaman hortikultura tahunan. Peningkatan fluktuasi, frekuensi dan intensitas anomali iklim dalam dasawarsa terakhir berdampak pada perubahan pola distribusi, intensitas dan periode musim hujan sehingga awal musim hujan maupun musim kering menjadi terlambat (Apriyana dan Tigia, 2015). Hal tersebut memungkinkan berdampak pada fluktuasi hasil produksi tanaman hortikultura tahunan yang mayoritas fase pembungaannya bergantung pada awal musim hujan atau musim kemarau.

Untuk mengetahui pengaruh perubahan pola distribusi, intensitas dan periode musim hujan dan kemarau terhadap produktivitas komoditas tanaman hortikultura harus menggunakan metode yang dapat mewakili curah hujan dan produktivitas. (Standardized Precipitation Index) SPI merupakan indeks kekeringan yang hanya mempertimbangkan presipitasi atau curah hujan dengan tujuan untuk mengetahui dan memonitoring kekeringan. Hasil perhitungan SPI merupakan index probabilitas dari data curah hujan dimana index negatif menunjukkan kondisi kering sedang indeks positif untuk kondisi basah. SPI dapat digunakan untuk memonitor kondisi dalam berbagai skala waktu (WMO, 2012). SPI merupakan metode yang dapat menggambarkan kondisi lingkungan dari data curah hujan dan data produktifitas merupakan data yang dapat mewakili produktivitas tanaman setiap pohon. Oleh karena itu perlu dilakukan pengkajian terhadap penyimpangan curah hujan terhadap normalnya, dalam suatu periode waktu yang panjang melalui metode standardized precipitation index (SPI) atau indek kekeringan terhadap produktifitas tanaman hortikultura tahunan (Durian, Alpukat, dan Rambutan).

\section{BAHAN DAN METODE}

Penelitian dilakukan mulai bulan Agustus 2016 - Desember 2018. Lokoasi penelitian berada pada 9 Kecamatan di Kabupaten Jember yang menyumbang produksi tanaman hortikultura tahunan (Durian, Alpukat, dan Rambutan) tertinggi. Pengolahan data dilakukan di Laboratorium Agroklimatologi Fakultas Pertanian Universitas Jember.

Data penelitian curah hujan berasal dari Dinas Pengairan Kabupaten Jember sedangkan data produksi dan jumlah tanaman berasal dari Dinas Pertanian Kabupaten Jember. Perhitungan klasifikasi iklim Schmidt-Ferguson menggunakan tolak ukur bulan basah dan bulan kering dari curah hujan untuk menentukan tipe iklimnya. Perhitungan produktifitas dilakukkan dengan cara membagi data produksi dengan jumlah tanaman. Perhitungan curah hujan menggunkan metode SPI (Standardized Precipitation Index) yang dikembangkan berdasarkan kuantifikasi defisit air pada berbagai skala waktu sehingga data presipitasi distandarisasi dan ditransformasikan hasil observasi ke dalam skala indeks kekeringan. Data SPI 12 bulanan dan produktivitas dikorelasi untuk mengetahui kuat dan bentuk hubungannya. Setelah itu data didandingkan dengan gafik silang untuk diketahui hal - hal yang terlibat dalam hubungan tersebut dan dampaknya pada produktifitas tanaman hortikultura.

Analisis kekeringan menggunakan SPI ini dapat dilakukan dengan berbagai periode, mulai dari 1 bulanan, 3 bulanan, 6 bulanan, 9 bulanan dan 12 bulanan bahkan lebih tergantung dengan kebutuhan analisis. Perhitungan nilai SPI berdasarkan jumlah sebaran gamma didefinisikan sebagai fungsi frekuensi atau atau fungsi probabilitas kepadatan sebagai berikut :

$$
\bar{G}(x)=\int_{0}^{x} g(x) \overline{d x}=\frac{1}{\beta^{\alpha} T(\alpha)} \int_{0}^{x} t^{a-1} e^{-x / \beta} d x
$$

$\alpha>0$, adalah parameter bentuk

$\beta>0$, adalah parameter

$\chi>0$, adalah jumlah curah hujan

Nilai standar normal random variable $\mathrm{Z}$ atau SPI tersebut lebih mudah dengan perhitungan menggunakan aproksimasi yang dikemukakan oleh Abramowitz dan Stegun (1964) dengan persamaan sebagai berikut,
Perhitungan $\mathrm{Z}$ atau SPI untuk $0<\mathrm{H}(\mathrm{x}) \leq 0,5$

$Z=S P I=-\left(t-\frac{c_{0}+c_{1}+c_{2} t^{2}}{1+d_{1}+d_{2} t^{2}+d_{2} t^{2}}\right)$ dengan $t=\sqrt{\ln \left(\frac{1}{(H(x))^{2}}\right)}$

Perhitungan $\mathrm{Z}$ atau SPI untuk $0,5<\mathrm{H}(\mathrm{x}) \leq 1,0$

$Z=S P I=-\left(t-\frac{c_{0}+c_{1}+c_{2} t^{2}}{1+d_{1}+d_{2} t^{2}+d_{2} t^{2}}\right)$ dengan $t=\sqrt{\ln \left(\frac{1}{1-(H(x))^{2}}\right)}$

Nilai: $\mathrm{c} 0=2.515517 ; \mathrm{c} 1=0.802853 ; \mathrm{c} 2=0.010328 ; \mathrm{d} 1=1.432788$; $\mathrm{d} 2=0.189269 ; \mathrm{d} 3=0.001308$

Kekeringan terjadi pada waktu SPI secara berkesinambungan negatif dan mencapai intensitas kekeringan dengan SPI bernilai -1 atau lebih kecil. Fleksibilitas dalam skala waktu ini membuat SPI dapat digunakan untuk aplikasi jangka pendek untuk pertanian maupun jangka panjang untuk hidrologi. Berdasarkan nilai SPI ditentukan tingkat kekeringan dan kebasahan dengan kategori sebagai berikut.

Tabel 2. Tetapan nilai SPI

\begin{tabular}{cc}
\hline SPI & Kategori \\
\hline$-2,00$ & Sangat Kering \\
$-1,50 \mathrm{~s} / \mathrm{d}-1,99$ & Kering \\
$-1,00 \mathrm{~s} / \mathrm{d}-1,49$ & Agak Kering \\
$-0,99 \mathrm{~s} / \mathrm{d} 0,99$ & Normal \\
$1,00 \mathrm{~s} / \mathrm{d} 1,49$ & Agak Basah \\
$1,50 \mathrm{~s} / \mathrm{d} 1,99$ & Basah \\
2,00 & Sangat Basah \\
\hline
\end{tabular}

Sumber: WMO (2012).

\section{HASIL DAN PEMBAHASAN}

SPI 1 Bulanan Nilai SPI 1 bulanan sangat mirip dengan data curah hujan yang menampilkan persentase curah hujan normal untuk jangka waktu 30 hari. Letak perbedaan antara SPI 1 bulanan dan cuah hujan 1 bulanan yaitu SPI memiliki tampilan data yang lebih akurat dari curah hujan bulanan karena distribusi telah dinormalisasi. SPI 1 bulanan memberikan kemudahan dalam membaca grafik dari pada data curah hujan 1 bulanan karena dapat deketahui kondisi fluktuasi kekeringan secara detail dari nilai yang terbagi menjadi kuadran positif dan negatif, sedangkan curah hujan hanya diketahui nilainya dan hanya bisa dikelompokkan menjadi bulan kering dan basah saja (Guttman, 1998).

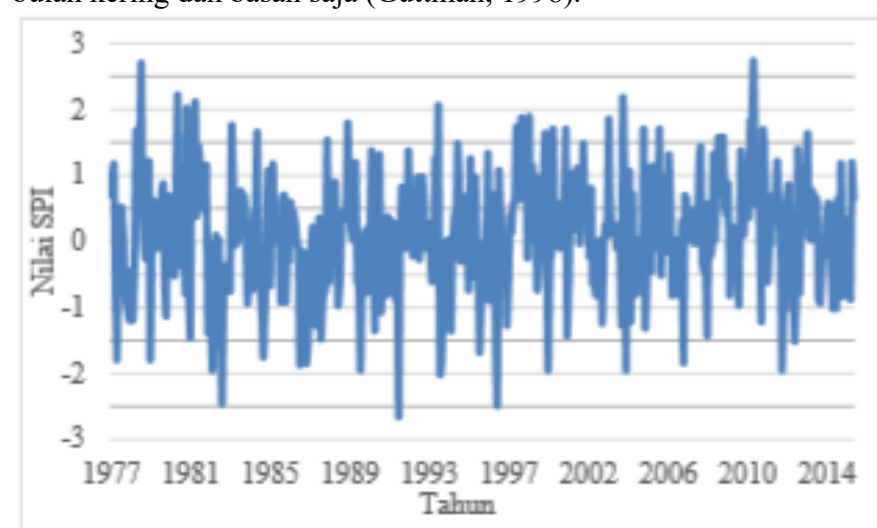

Gambar 1. Grafik Nilai SPI 1 Bulanan Kecamatan Sukowono Tahun 1977-2015.

SPI 1 bulanan mencerminkan kondisi jangka pendek, aplikasinya dapat berhubungan erat dengan jenis meteorologi kekeringan bersama dengan kelembaban tanah jangka pendek dan stres tanaman, terutama selama musim tanam. SPI 1 bulanan mendekati kondisi diwakili oleh Indeks Crop Moisture, yang merupakan bagian dari Palmer Drought Severity Index suite indeks (WMO, 2012). 


\section{SPI 3 Bulanan}

Nilai SPI 3 Bulanan mencerminkan kondisi kelembaban jangka pendek dan menengah serta memberikan estimasi curah hujan musiman. Di daerah pusat pertanian, SPI 3 bulanan lebih efektif dalam menyoroti kondisi kelembaban yang tersedia dari Palmer Indeks yang lambat merespons atau indeks hidrologi lainnya yang tersedia saat ini (McKee et al, 1993).

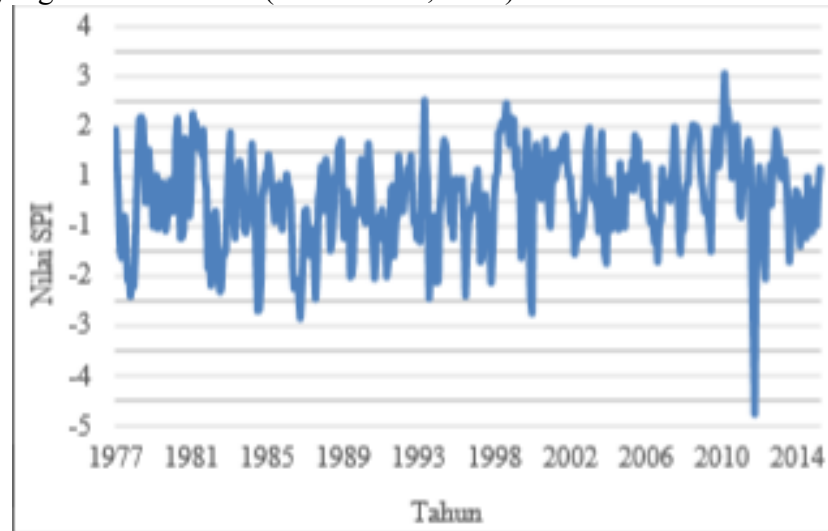

Gambar 2. Grafik Nilai SPI 3 Bulanan Kecamatan Sukowono Tahun 1977-2015.

SPI negatif atau positif yang besar dapat dikaitkan dengan curah hujan total tidak jauh berbeda dari rata - rata (WMO, 2012). SPI 3 bulanan sesui digunakan untuk pengamatan komuditas tanaman semusin.

\section{SPI 6 Bulanan}

Nilai SPI 6 bulanan menunjukkan musiman tren jangka menengah curah hujan dan masih dianggap lebih peka terhadap kondisi pada skala ini dari pada Indeks Palmer. SPI 6 bulanan dapat sangat efektif dalam menunjukkan curah hujan yang berlebih dari musim yang berbeda (WMO, 2012)

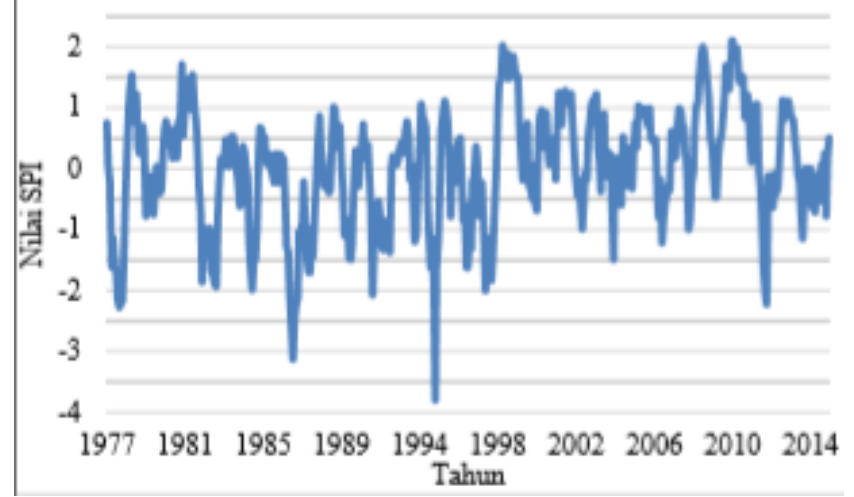

Gambar 3. Grafik Niali SPI 6 Bulanan Kecamatan Sukowono Tahun $1977-2015$

Informasi dari SPI bulanan juga mulai dikaitkan dengan anomali aliran sungai dan tingkat ketersediaan air di waduk, tergantung pada daerah dan waktu tahun (WMO, 2012).Dilihat dari tren waktunya SPI 6 bulanan dapat digunakan dalam pengamatan komuditas tanaman holtikultura semusim.

\section{SPI 9 Bulanan}

Nilai SPI 9 bulanan memberikan indikasi pola curah hujan antar musim dengan durasi skala waktu menengah. Kekeringan biasanya mengikuti musim atau lebih sering terjadi. Nilai-nilai SPI di bawah -1,5 menjadi indikasi untuk mengetahui bahwa kekeringan memiliki dampak yang signifikan pada sektor pertanian dan dapat mempengaruhi sektor-sektor lain juga. Di beberapa negara di tenemukan bahwa pola yang ditampilkan oleh peta Indeks Palmer berkaitan erat peta SPI 9 bulan. Sedangkan untuk negara lain, Indeks Palmer lebih erat terkait dengan 12 bulan SPI (WMO, 2012).

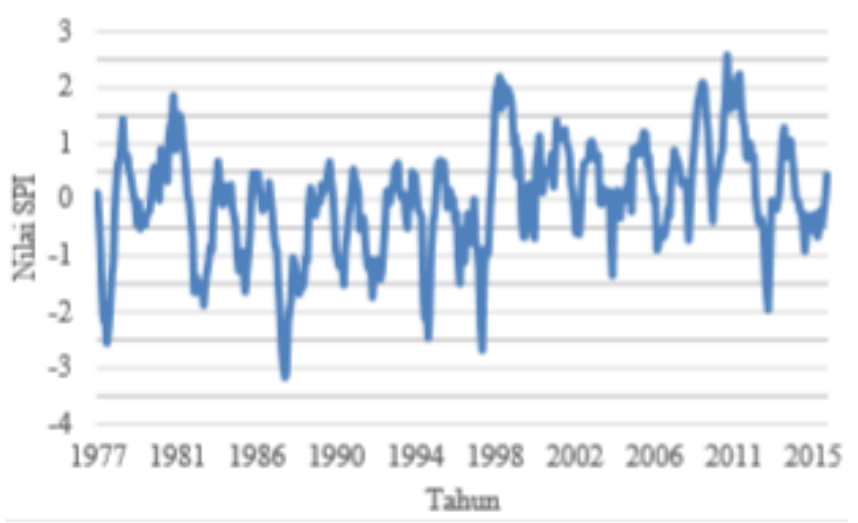

Gambar 4. Grafik Nilai SPI 9 Bulanan Kecamatan Sukowono Tahun 1977-2015.

Periode waktu SPI 9 bulanan menjadi penghubung kekeringan musiman jangka pendek dan kekeringan jangka panjang pada berbagai negara (WMO, 2012). SPI 9 bulanan memiliki tren yang sesuai digunakan dalam pengamatan komoditas tanaman dengan siklus tahunan.

\section{SPI 12 Bulanan}

Nilai SPI 12 bulan mencerminkan pola curah hujan jangka panjang. SPI dari rentang waktu ini biasanya terkait dengan aliran sungai, tingkat ketinggihan waduk, dan tingkat ketinggihan air tanah di rentang waktu yang lebih panjang. SPI 12 bulanan merupakan perbandingan curah hujan selama 12 bulan berturut-turut dengan 12 bulan berturut-turut yang sama dalam semua data tahun yang tersedia sebelumnya. Karena rentang waktu ini adalah hasil kumulatif dari periode yang lebih pendek yang mungkin berada di atas atau di bawah normal, nilai SPI cenderung tertarik ke arah nol kecuali tren basah atau kering khas berlangsung (WMO, 2012).

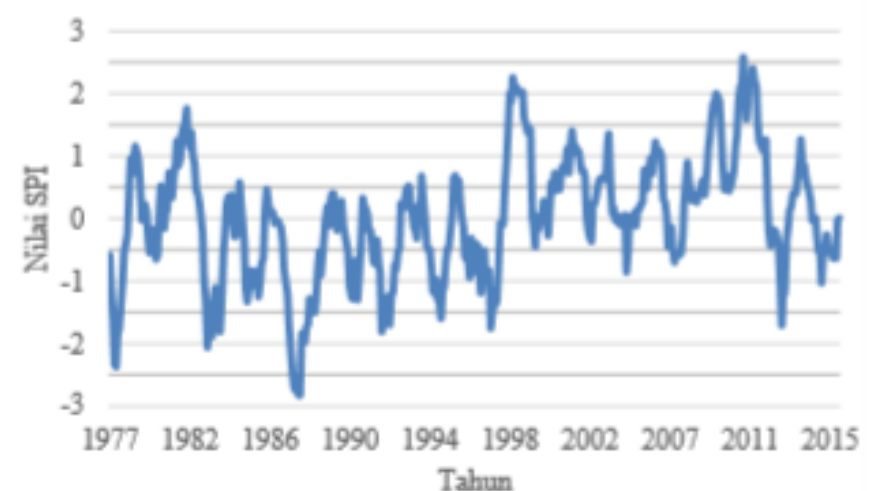

Gambar 5. Grafik Nilai SPI 12 Bulanan Kecamatan Sukowono Tahun 1977-2015.

Pada beberapa negara SPI 12 bulanan paling berhubungan erat dengan Index Palmer dan dimungkinkan juga kedua indeks tersebut mencerminkan kondisi yang sama (WMO, 2012). SPI 12 bulanan sangat sesuai digunakan sebagai parameter pengamatan produktivitas tanaman tahunan termasuk tanaman hortikultura tahunan.

\section{Pengaruh SPI Terhadap Produktivitas Durian}

Pencatatan Dinas Pertanian Kabupaten Jember tahun 2004 2014 diperoleh hasil tertinggi produksi durian terjadi di Kecamatan Bangsalsari, Sumberjambe, Sukowono, dan Ledokombo yang sudah mewakili lebih $50 \%$ produksi di Kabupaten Jember. Pohon Durian rata - rata berbunga pada musim kemarau atau pada bulan Juni September dan bisa dipanen setelah 4-5 bulan yaitu sekitar bulan Oktober - Februari (Jumali, 2011). Berdasarkan bulan panen durian dalam 1 tahun terdapat 2 kali panen rata - rata pada bulan Oktober Desember dan Januari - Februari, namun panen tersebut masih dalam 1 siklus berbuah pohon durian. 


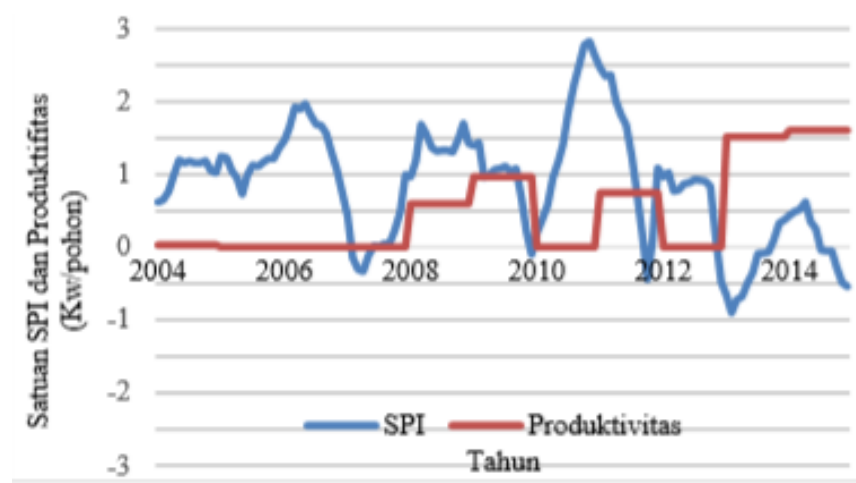

Gambar 6. Grafik Perbadingan Nilai SPI 12 bulanan dan Produktifitas Durian Kecamatan Bangsalsari Tahun 2004-2014.

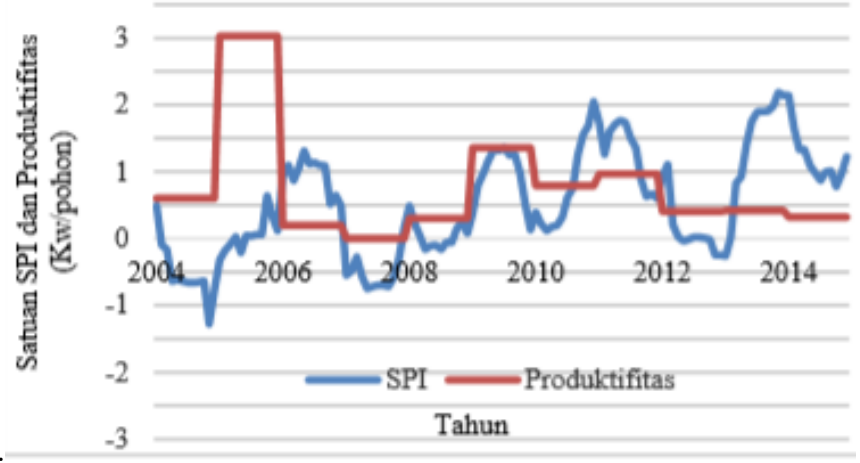

Gambar 7. Grafik Perbadingan Nilai SPI 12 bulanan dan Produktifitas Durian Kecamatan Sumberjambe Tahun 2004-2014.

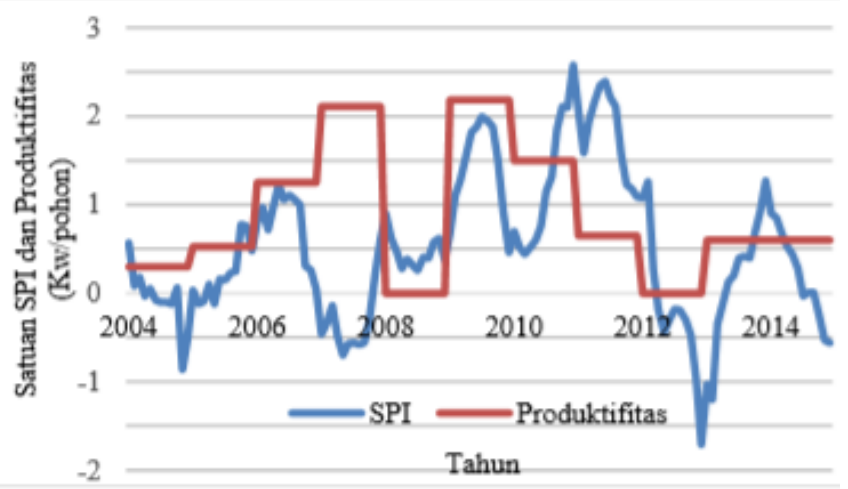

Gambar 8. Grafik Perbadingan Nilai SPI 12 bulanan dan Produktifitas Durian Kecamatan Sukowono Tahun 2004-2014

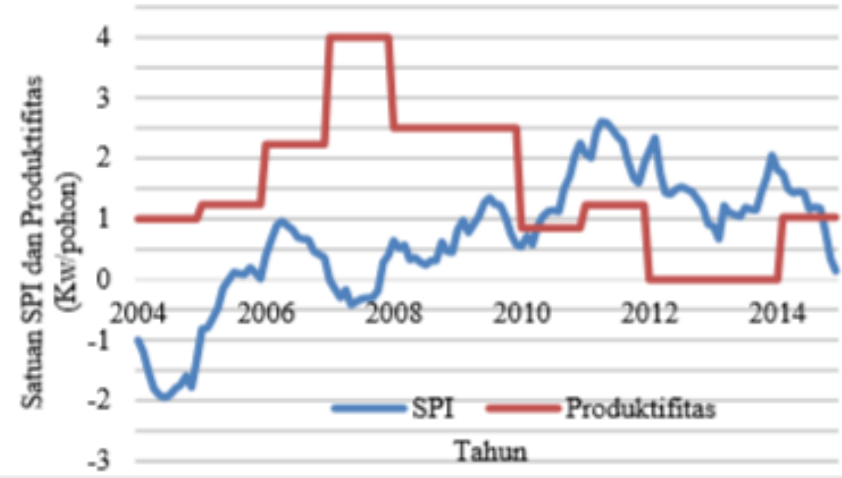

Gambar 9. Grafik Perbadingan Nilai SPI 12 bulanan dan Produktifitas Durian Kecamatan Ledokombo Tahun 2004-2014.

Produktivitas tertinggi terjadi saat nilai SPI pada bulan JuniSeptember saat pembentukan bunagn berada pada kondisi normal dan cendrung naik pada Oktober-Februari saat pembentukan buah. Sedangkan produktivitas terendah terjadi saat nilai SPI pada bulan Juni-September pada kondisi basah atau normal mendekati basah dan cendrung turun atau ekstrem naik pada Oktober-Februari saat pembentukan buah.

Tren grafik Kecamatan Sukowono dan Ledokombo berbanding lurus antara nilai SPI dan produktivitas sedangkan tren grafik Kecamatan Bangsalsari dan Sumberjambe berbanding terbalik. Hubungan nilai SPI dan produktivitas adalah berpengaruh signifikan di Kecamtan Sukowono, Ledokombo dan Bangsalsari dengan nilai $r=0,247^{* *}$, nilai $r=0,229^{* *}$, dan $r=-0,436^{* *}$. Di Kecamatan Sukowono dan Ledokombo semakin tinggi nilai SPI maka produktivitas meningkat sedangkan di Kecamatan Sumberjambe sebaliknya. Pada Kecamatan Sumberjamber tidak ada hubungan antara nilai SPI dan produktivitas dengan nilai $r=-0,025$.

Durian berbunga pada bulan Juni sampai September dan membutuhkan periode kering untuk merangsang pembungaan sehingga bunga akan mekar pada 6-8 minggu setelah putik sempurna (Arianty, 2018). Kondisi iklim sangat sesuai dengan syarat tumbuh durian yang menghendaki 1-2 bulan periode kering untuk merangsang pembungaan dan menghendaki curang hujan cukup saat proses pembentukan buah sampai panen (Setiadi, 2002) Jumlah bunga mekar tidak diikuti dengan jumlah buah yang terbentuk disebabkan pada saat menjelang bunga mekar intensitas curah hujan tinggi sehingga menyebabkan banyak bunga yang rontok sebelum terbentuk buah (Rahmanto et al, 2000).

La-Nina yang menyebabkan intensitas curah hujan terlalu tinggi menyebabkan gagalnya pembungaan dan El-Nino menyebabkan intensitas curah hujan tetap rendah setelah pembungaan membuat bunga atau bakal buah rontok. La-Nina berperan lebih besar menyebabkan penurunan produksi durian dari pada El-Nino dan paparan ENSO yang paling terpengaruh adalah Jawa dan Sumatera (Sarvima dan Kharmila, 2017).

\section{Pengaruh SPI Terhadap Produktivitas Alpukat}

Pencatatan Dinas Pertanian Kabupaten Jember tahun 20042014 diperoleh rata - rata tertinggi produksi Alpukat terjadi di Kecamatan Tempurejo, Silo, Ledokombo, dan Tanggul yang sudah mewakili lebih $50 \%$ produksi di Kabupaten Jember.

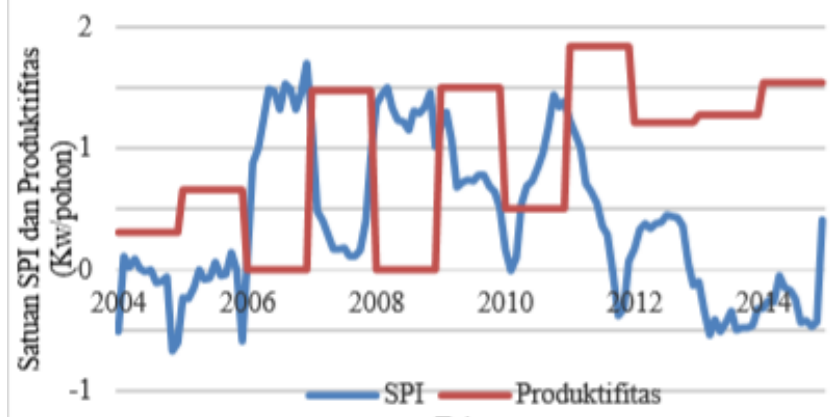

Tahun

Gambar 10. Grafik Perbadingan Nilai SPI 12 bulanan dan Produktifitas Alpukat Kecamatan Tempurejo Tahun 2004-2014.

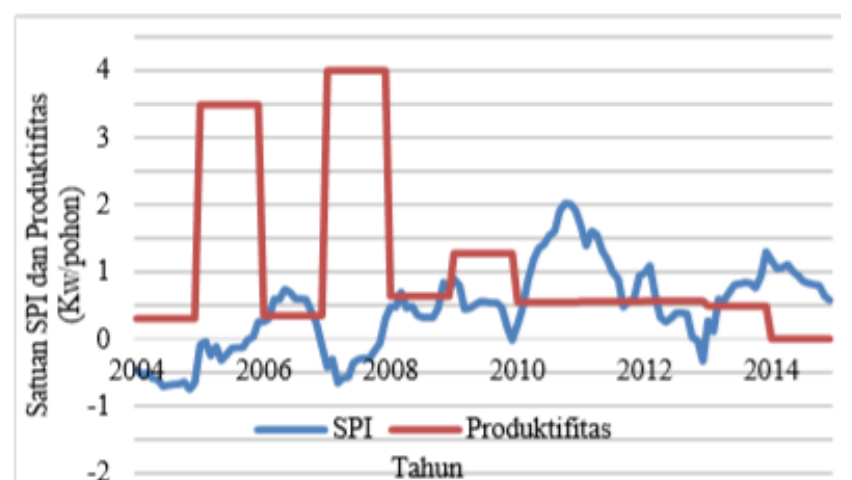

Gambar 11. Grafik Perbadingan Nilai SPI 12 bulanan dan Produktifitas Alpukat Kecamatan Silo Tahun 20042014 


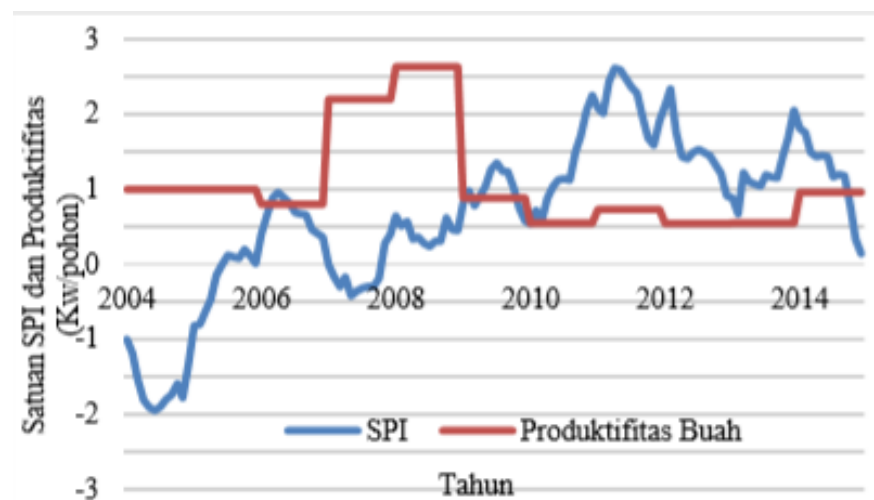

Gambar 12. Grafik Perbadingan Nilai SPI 12 bulanan dan Produktifitas Alpukat Kecamatan Ledokombo Tahun 2004-2014

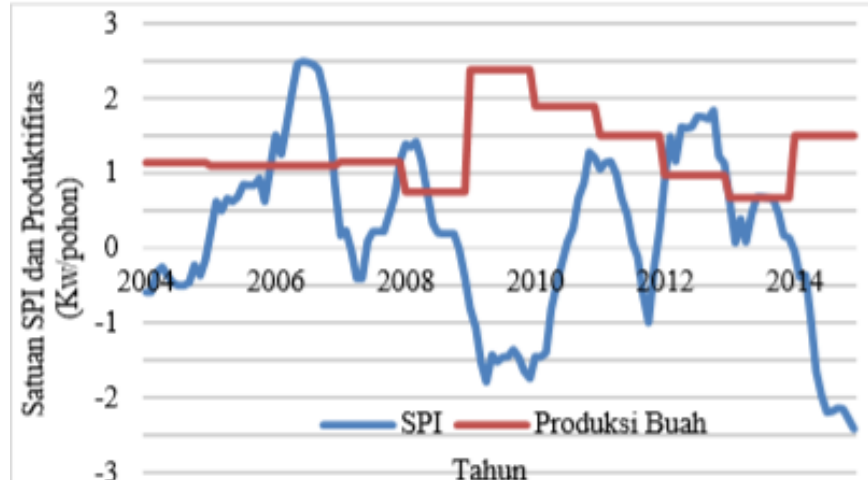

Gambar 13. Grafik Perbadingan Nilai SPI 12 bulanan dan Produktifitas Alpukat Kecamatan Tanggul Tahun 2004-2014.

Alpukat menghendaki nilai SPI normal untuk mencapai kondisi sempurna dalam siklus pembentukan buah hingga pembentukan buah. Produktivitas tertinggi tercatat pada tahun 2011 sebesar 1,84 kw/pohon dan diikuti di tahun 2007, 2009, 2011 dan 2014. Pada tahun tersebut terjadi La-Nina moderat di 2007 dan 2011, El-Nino moderat di 2009 dan El-Nino lemah di 2014. (Sarvima dan Sari, 2017). Pengaruh ENSO pada tahun tersebut tergolong stabil sehingga sesuai dengan agroklimat yang dibutuhkan alpukat untuk berpoduktivitas optimal.

Produktifitas terendah tercatat pada tahun 2006 dan 2008 sebesar 0 kw/pohon. Pada tahun 2006 dan 2008 nilai SPI menunjukkan kondisi rata-rata basah dan sedikit agak basah. Penurunan produktivitas alpukat dikarenakan rentan terhadap genangan air intensitas hujan yang lebat. Tanaman alpukat tumbuh optimal pada tanah gembur, subur banyak mengandung bahan organik dan tidak mudah tergenang. Pada kondisi tegenang saat $\mathrm{pH}$ di bawah 5,5 maka tanaman akan menderita keracunan karena unsur $\mathrm{Al}, \mathrm{Mg}$ dan Fe larut cukup banyak (Sobir, 2009).

Tren grafik Kecamatan Tempurejo, Silo, Ledokombo dan Tanggul berbanding terbalik antara nilai SPI dan produktivitas. Hubungan nilai SPI dan produktivitas adalah berpengaruh signifikan dengan nilai $\mathrm{r}=-0,455^{* *}, \mathrm{r}=-0,392^{* *}, \mathrm{r}=-0,363^{* *}, \mathrm{r}=-0,561^{* *}$. Semakin tinggi nilai SPI maka produktivitas menurun.

Tanaman alpukat memerlukan bantuan angin dalam proses penyerbukan bunga namun sangat berbahaya jika angin terlalu besar, angin dengan kecepatan 62,4-73,6 km/jam dapat mematahkan ranting dan percabangan yang tergolong rapuh dan lunak. Alpukat yang tumbuh pada kondisi yang sesuai akan berbuah 2-3 kali dalam setahun berbuah lebat pada bulan Januari -Februari, berbuah sedikit pada bulan Mei-Juni, dan lebat kembali November-Desember (Sadwiyanti, 2009).

\section{Pengaruh SPI Terhadap Produktivitas Rambutan}

Pencatatan Dinas Pertanian Kabupaten Jember tahun 20042014 diperoleh rata-rata tertinggi produksi rambutan terjadi di
Kecamatan Bangsalsari, Patrang, Tanggul, Sukorambi dan Sumberbaru yang sudah mewakili lebih $50 \%$ produksi di Kabupaten Jember.

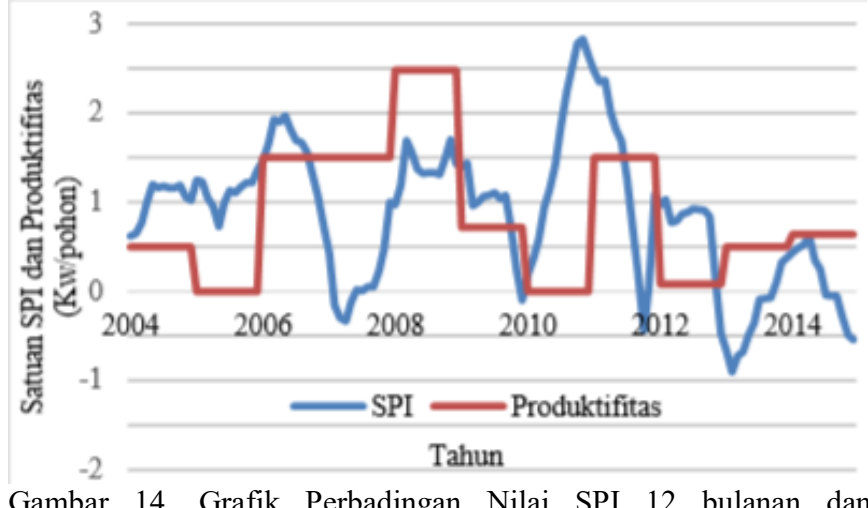

Gambar 14. Grafik Perbadingan Nilai SPI 12 bulanan dan Produktifitas Rambutan Kecamatan Bangsalsari Tahun 2004-2014

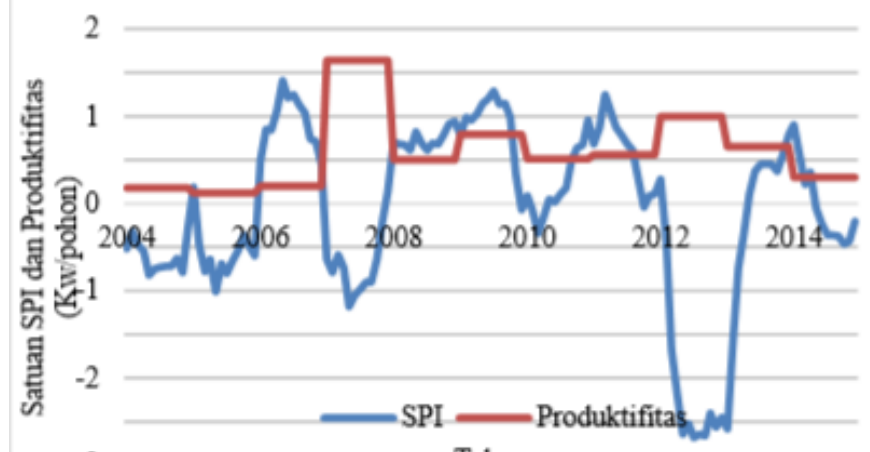

$-3$

Gambar 15. Grafik Perbadingan Nilai SPI 12 bulanan dan Produktifitas Rambutan Kecamatan Patrang Tahun 2004-2014

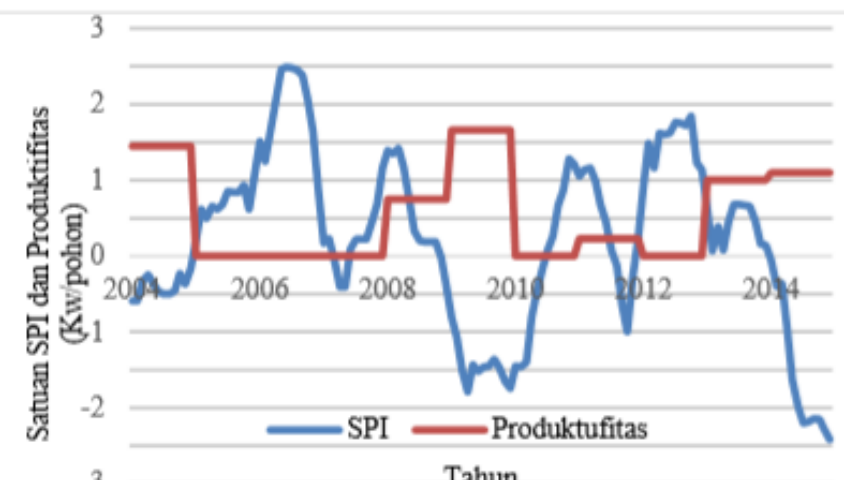

Gambar 16. Grafik Perbadingan Nilai SPI 12 bulanan dan Produktifitas Rambutan Kecamatan Tanggul Tahun 2004-2014

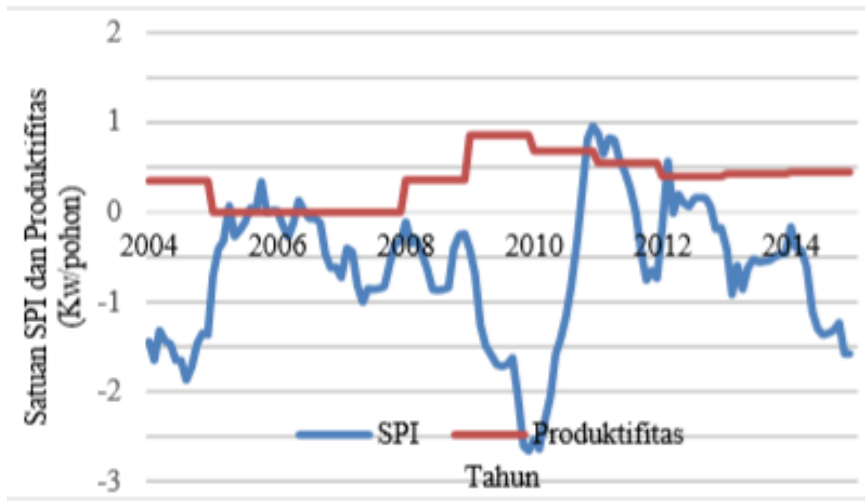

Gambar 17. Grafik Perbadingan Nilai SPI 12 bulanan dan Produktifitas Rambutan Kecamatan Sumberbau Tahun 2004-2014. 
Pencatatan Dinas Pertanian Kabupaten Jember tahun 20042014 diperoleh rata-rata tertinggi produksi rambutan terjadi di Kecamatan Bangsalsari, Patrang, Tanggul, Sukorambi dan Sumberbaru yang sudah mewakili lebih $50 \%$ produksi di Kabupaten Jember.

Produktifitas tertinggi tercatat pada tahun $2006-2009$ di hampir semua kecamatan. Pada tahun tersebut nilai SPI awal tahun menunjukkan kondisi sangat basah kemudian turun menjadi basah lalu naik kembali menjadi sangat basah pada triwulan akhir bulan. Kondisi tesebut sangat sesuai dengan agoklimatologi tanaman rambutan yang membutuhkan kondisi bulan kering saat berbunga kemudian membutuhkan bulan basah saat menginjak fase pertumbuhan dan pematangan buah (Masisworo, dkk, 1990).

Produktifitas terendah tercatat pada tahun 2005 dan 2007 hampir di semua kecamatan. Pada tahun tersebut tersebut SPI mengalami kenaikan dari agak basah menuju basah yang artinya intensitas curah hujan meningkat sepanjang tahun. Rambutan mampu tumbuh pada segala tipe-tanah, asal cukup mengandung bahan organik tetapi tidak tahan pada air yang dangkal dan menggenang (Sabaruddin, 2012).

Tren grafik Kecamatan Sumberbaru berbanding terbalik antara nilai SPI dan produktivitas sedangkan Kecamatan Bangsalsari berbanding lurus. Tidah ada hubungan anatar nilai SPI dan produktivitas dengan nilai $r=-0,096$ dan $r=0,131$. Tren grafik Kecamatan Tanggul dan Patrang berbanding terbalik antara nilai SPI dan produktivitas. Hubungan nilai SPI dan produktivitas adalah berpengaruh signifikan dengan nilai $\mathrm{r}=-0,635^{* *}$ dan $-0,292^{* *}$. Semakin tinggi nilai SPI maka produktivitas menurun.

Pohon rambutan tumbuh disegala jenis tanah yang subur mengandung banyak bahan organik tetapi tidak tahan pada air dangkal dan menggenang. Rambutan berbunga pada musim kemarau atau 3 bulan kering beruntun, hujan yang jatuh saat pohon berbunga menyebabkan bunga gugur dan terserang penyakit mildu tepung (Oidium sp), dan apabila kemarau berkepanjangan juga membuat daging buah tipis. Musim panen rambutan pada bulan Desember Februari buah dapat dipetik setelah umur 120 hari dari anthesis (bunga mekar) (Masisworo, dkk, 1990).

Di daerah dengan musim kering relatif panjang, tanaman rambutan sering menunjukkan gejala kering tepi daun atau nekrosis, terutama pada musim kering sekitar bulan Juni - Agustus. Angin kering dapat memacu transpirasi sehingga daun tanaman kekurangan air karena penyerapan air di tanah yang kering tidak mampu mengimbangi kehilangan air. Air mempunyai peranan sangat penting bagi kehidupan tanaman, antara lain berfungsi sebagai penyusun utama protoplasma dan sebagai pelarut serta pembawa berbagai senyawa termasuk nutrisi (Pandey dan Sinha, 1981).

\section{KESIMPULAN}

1. Nilai SPI 12 bulanan sesuai untuk mengamati produktivitas tanaman tahunan.

2. 2. SPI 12 bulanan berpengaruh signifikan terhadap produktivitas hotikultura tahunan (durian, alpukat dan rambutan). Nilai SPI yang semakin tinggi menaikkan produktivitas durian dan menurunkan produktivitas alpukat dan rambutan. Nilai SPI yang semakin rendah menurunkan produktivitas durian dan menaikkan produktivitas alpukat dan rambutan.

\section{SARAN}

Berdasarkan hasil penelitian yang sudah dilakukan, metode SPI 12 bulanan sangat sesuai untuk mengetahui perkembangan fluktuatif produktivitas hortikultura tahuan. Hal ini terjadi karena SPI memiliki keunggulan dapat membaca kondisi iklim yang dikehendaki tanaman hortikultura tahunan. Oleh karena itu pedugaan produktivitas di waktu yang akan datang dapat menggunakan metode SPI yang telah diketahui pola fluktuasinya.

\section{DAFTAR PUSTAKA}

Apriyana, Yayan dan Tigia Eloka Kailaku, T.E. 2015 Variabilitas Iklim dan Dinamika Waktu Tanam Padi di Wilayah Pola Hujan Monsunal dan Equatorial. Prosiding Seminar Nasional Biodiversiti Indonesia, 1(2) : 366-372.

Ariyanti, Endang. 2018. Pengaruh Perubahan Iklim Terhadap Produksi Buah Durian Pada Sistem Agoforestri Di Desa Pappadangan kecamatan Anreapi Kabupaten Poliwali Mandar. Tugas Akhir. Univesitas Hasanuddin Makassar.

Guttman NB. 1998. Comparing the Palmer Drought Index and the Standardized Precipitation Index. J Amer. Water Resour. Assoc., 34(1):113-121.

Jumali. 2011. Pedoman Budidaya Tanaman Durian (Durio Zibethinus). Sleman: Dinas Kehutanan Kabupaten Sleman.

Masisworo, K. Sutanto, dan A. Anung. 1990. Bartanaman Rambutan. Jakarta: Panebar Swadaya.

McKee, T.B., Doesken, N.J., and Kleist,J. 1993. The Relationshio of Drought Frequency and Duration to Time Scales, Procedings of the 8th Conference on Applied Climatologi.

Nandini, Ryke dan Budi Hadi Narendra. 2011. Kajian Perubahan Curah Hujan, Suhu dan Tipe Iklim Pada Zone Ekosistem di Pulau Lombok. Analisis Kebijakan Kehutanan, 8(3) : 228244.

Pandey, S. N. dan B. K. Sinha. 1981. Plant Physiology 3rd .New Delhi: House P.V.T Ltd.

Rahmanto, A., Fajriani, S., Hariyono, D. 2018. Hubungan Iklim dan Produksi Tanaman Durian Lokal (Durio zibethius Murr.) di Tiga Lokasi (Bangkalan, Wonosalam, dan Ngantang). Produksi Tanaman 6(9) : 2000-2006.

Sabaruddin, Laode. 2012. Agroklimatologi Aspek - Aspek Klimatologi untuk Sistem Budidaya Tanaman. Bandung: Alfabeta.

Sadwiyanti, L. Djoko Sudarso, dan Tri Budiyanti. 2009. Petunjuk Teknis Budidaya Alpukat. Solok: Balai Penelitian Buah Tropika.

Sarvima, Yeli dan Kharmila Sari. 2017. Dampak ENSO terhadap Produksi dan Panen Durian di Indonesia. Tanah dan Iklim 41(2) : $149-158$.

Setiadi. 2002. Bertanam Durian. Jakata: Penebar Swadaya.

Sobir. 2009. Budi Daya Tanaman Buah Unggul Indonesia. Jakarta: Agromedia.

World Meteorological Organization (WMO). 2012. Standardized Precipitation Index User Guide. Geneva Switzerland: Publications Board World Meteorological Organization. 